\title{
Editorial
}

\section{The Last Waltz}

\section{Rachel Dunn, Northumbria University}

The Last Waltz was the farewell concert of The Band and feels a very fitting name for what is my final editorial and issue of the Student Journal. They played for over four hours and were joined by some of the greats, including Joni Mitchell, Van Morrison, Neil Young and Bob Dylan. Now, I am not saying that I consider myself to be on the same level as those playing in The Last Waltz, but I have worked with some Rockstar students during my time as Editor of the Student Journal. They have put in a credible amount of work into these publications, have demonstrated passion for the subject areas and been incredible to work with. As Editor of this journal, I have been joined by some of the greats, who have made my Last Waltz very bittersweet.

It has been a strange year for all of us, and Covid-19 has disrupted many of our lives and, for our students, their university experiences. I am sorry that there was not a second issue last summer, but with everything going on it just didn't feel like the time to ask students and staff to work even harder than they already were. What I have done, however, is saved some treats for you in this issue, collected over many months, which I hope you enjoy and find it to be an escape from the current difficulties we face.

In this issue, we have two articles written by two year 4 students at Northumbria Law School. Jade Potot-Warren, who you may remember from the last issue, is back with another thoughtprovoking article. In this issue, Jade explored whether the current sex work laws in England and Wales are outdated. She puts forward proposals for reform, exploring laws from other countries such as New Zealand. Jade establishes an important argument as to why sex work needs to be legalised, in order to help and protect sex workers. Our second article is by Luke Johnson, exploring the impact of Brexit on the habitat conservation regime in England and Wales. Having taught Luke in the Policy Clinic, where we looked at the Bern Convention, the passion he feels for environmental law is clear in this article. He discusses the variety and complex network of laws which make up the conservation regime in England and Wales and assesses the consequences of the UK's exit from the EU. It has been a pleasure working with Luke on this research, and I look forward to working with him further in the future. 
There are three dissertations in this final issue, all from Northumbria Law School graduates. These students produced some excellent research. Since graduating they have been kind enough to share their dissertation advice with current students who are starting their own dissertation journeys.

Our first dissertation is by Nathan Maddison, who undertook a legal history dissertation, which involved him engaging with the Tyne and Wear Archives. His curiosity in coal mines started at a young age when he read Roy Thompson's How Long did the Ponies Live? The Story of the Colliery at Killingworth and West Moor. Nathan focuses on the Government Inspectors who would visit collieries, considering the extent to which they were a 'panacea for the 'evils' associated with the coal mining in the United Kingdom during the nineteenth century.' It is an amazing body of work and a pleasure to read.

Sophie Quince's dissertation explores the law surrounding responsibility and accountability for Autonomous Weapons Systems (AWS), arguing that the laws are insufficient and, at an international level, are not equipped to deal with the challenges posed by AWS. Technology is expanding fast, and Sophie highlights the need for academic discussion into the legal and ethical issues of it, specifically the appropriate use of AWS. She recognises that though there are arguments that this can 'create a more precises and humane method of warfare...others suggest that actually it creates a human rights dilemma.' It is a great insight into how the law struggles to keep up with technological changes, and the drastic impact this can have on the world.

The final dissertation is by Daniel Hails, exploring the protection animals receive in the legal system, with a specific focus on sentencing for animal welfare offences and making the argument that sentencing for these offences needs to be reformed. Daniel explores the variety of sentences available to the courts, including custodial sentences and disqualification orders. This is a comparative dissertation, and Daniel draws upon laws and systems in other countries throughout the EU and the US, with suggestion of how England and Wales can keep up with developments across the world. He frames his research around Donaldson and Kymlicka's theory of citizenship, Zoopolis, outlining how citizenships status for animals could contribute to the increase of protection for this within the legal system, particularly in sentencing. This is 
a timely dissertation, when the Animal Welfare (Sentencing) Bill 2019-21, which aims to increase sentencing of Animal Welfare Act 2006 offences to 5 years, is struggling to make its way through Parliament.

Lastly, we have the selection of highly commended posters from this year's Poster Conference at Northumbria Law School, which had to be held virtually this year. As this is the third year we have published these posters, I feel confident now saying that this is a tradition! The posters from this year's LLB and M Law students explore a variety of topics, including non-disclosure agreements in sexual harassment cases, laws surrounding disposal of the dead, surrogacy and decriminalisation of drugs. It has been a pleasure, as always, to look at the variety of posters and I am amazed year after year of the creativity of our students. As always, please remember that these are first year students who have undertaken an independent research project in an unfamiliar area of law, so whilst some aspects may not be completely correct, the hard work and academic skills are evident.

So, that is a wrap on my Last Waltz as Editor of the Student Journal. It has been an extremely rewarding few years working on this and I am going to miss working with our amazing students on the journal. It is time, however, to pass on the baton and allow for another Editor to leave their mark and inspire our students to put their work out there. My hope is that Student Journal continues to expand and more students from different disciplines and universities continue to contribute. I want to thank my colleagues for the continuous support throughout my time as Editor, without whom this work would not be possible. I want to thank the students I have worked with over the years, who have been passionate and patient. Lastly, I want to thank you, the readers, for taking the time to read the work which has been published in this journal over the last few years. As I listen to The Weight by The Band, I think it is time I took a load off. Thank you for reading! 